\title{
Founders Versus Descendants: Evidence Of The Taiwanese Publicly Traded Firms
}

M. Monica Her, (E-mail: monica.her@csun.edu), California State University, Northridge Thomas G. E. Williams, (E-mail: williamst@wpunj.edu), William Paterson University

\begin{abstract}
This study investigates the performance of founder-controlled firms vis-à-vis firms controlled by founders' descendants and relatives among Taiwanese publicly traded firms. After adjusting for size, age, growth potential, financial leverage, and industry effects, we find that the Taiwanese descendant-controlled firms underperform the matching founder-controlled firms. In searching for the potential reasons, we find that the average board size for the descendant-controlled firms is significantly larger than that of the founder-controlled firms. In addition, the ratios of familyrelated supervisors and board members of the descendant-controlled firms are significantly higher than those of the matching founder-controlled firms. While the significantly larger board size suggests a potential power struggle between the controlling family and the non-family related board members, the stronger family domination in the board of directors and supervisors for the descendant-controlled firms provides room for entrenchment and tunneling. In light of the absence of large outside blockholders and relatively weaker legal protections, the minority shareholders of Taiwanese firms are dependent upon internal monitoring mechanisms to protect them from the expropriation of the controlling families. However, our results indicate that family control has undermined the internal monitoring mechanism of the Taiwanese descendantcontrolled firms.
\end{abstract}

\section{Introduction}

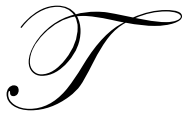

his study investigates the performance of founder-controlled firms vis-à-vis firms controlled by founders' descendants and relatives among Taiwanese publicly traded firms. Since Berle and Means first established the agency theory of the modern corporation in 1932, the whole stream of agency theory literature focuses on the agency problems created by the separation of ownership and the control of resources acquired by ownership. After Jensen and Meckling (1976) published their ownership theory, most of the researchers investigated the relationship between managerial ownership and firm performance with a focus on U.S. firms. It is La Port, Lopez-de-Silanes, and Shleifer (1998) who provide the first broad investigation on equity ownership across countries. The authors contend that family control of publicly traded firms is the norm of the non-U.S. world. However, the existing literature provides little evidence on the characteristics of the controlling families and how these controlling families affect firm performance.

DeAngelo and DeAngelo (1985), Holderness and Sheehan (1988) and Denis and Denis (1994) are the few studies that examine family control of publicly-listed U.S. firms. They do not find evidence of expropriation of minority shareholders' wealth by the controlling families. However, since their sample firms are all majority-owned by the controlling families, they cannot disentangle the family-control effects from the ownership effects. Morck, Shleifer and Vishny (1988), McConaughy, Walker, Henderson and Mishra (1998), and McConaughy and Phillips (1999) are among a few studies that examine the relationship between founder control and firm characteristics of the U.S. publicly traded firms. Morck, Shleifer, and Vishny, examine the founder effect on firm performance. They

Readers with comments or questions are encouraged the authors via email 
report that the presence of the founding family as the two top officers -- the chief executive officer (CEO) and the president -- reduces firm value for firms incorporated before 1950, but increases firm value for those incorporated in 1950 or later. The authors suggest that the descendents are too entrenched at the older firms, making it difficult to remove them, as one potential explanation for the contrast. McConaughy and Phillips investigate the characteristics of the founder-controlled versus the descendant-controlled firms. However, they find that their sample of descendant-controlled firms is more profitable than their sample of founder-controlled firms.

In light of the mixed results documented for the U.S. firms, our study provides new evidence on the characteristics of founder-controlled and descendant-controlled firms using firms in the Taiwanese market. We select the Taiwanese market for our study because of the following desirable characteristics. First, as one of the "Far East Asia Tigers", Taiwan is ranked the $13^{\text {th }}$ largest economy in the world with more than $90 \%$ of its GDP generated by family-controlled firms. The majority of the Taiwanese listed firms are run and controlled by the founding family even though the family may not be the majority owner. This unique feature allows us to disentangle the family-control effects from the ownership effects. Second, rooted as it is in the German civil law system, the Taiwanese board structure is a hybrid between the U.S. and the U.K. unitary board structure and the German two-tier board structure. However, unlike the German system, which puts into place an independent supervisory board to supervise the managerial board, the Taiwanese system institutes individual shareholders as supervisors to monitor the CEO and the board of directors. The functions of the Taiwanese board of directors are similar to that of the U.S. inside board members, while the functions of the Taiwanese supervisors are similar to that of the U.S. outside board members. A third distinct feature is the ownership structure. Unlike the U.S. and the U.K. where institutional investors own more than $60 \%$ of the equity ownership, the average equity holdings in the Taiwanese firms by institutional investors is well below 10\%. Therefore, the incentive for the Taiwanese institutional investors to monitor the incumbent is much lower than that of the U.S. and the U.K. institutional investors. This lack of external monitoring leaves the minority shareholders dependent upon the internal monitoring mechanism -- supervisors -- to protect them from expropriation by the controlling family.

Our sample includes 30 Taiwanese descendant-controlled firms and 30 matching founder-controlled firms. Our study period covers from 1990 to 1997. As in other newly developing markets, the Taiwanese firms are relatively young compared to their counterparts in more advanced markets. Our Taiwanese descendant-controlled firms tend to be older and larger than the founder-controlled firms in the same industry. After adjusting for size, age, growth potential, financial leverage, and industry effects, we find that the Taiwanese descendant-controlled firms underperform the matching founder-controlled firms. Our results are consistent with those reported by Morck, Shleifer, and Vishny. (1988), but differ from those reported by McConaughy and Phillips (1999). In searching for the potential explanation of why the Taiwanese descendant-controlled firms under perform their counterpart of founder-controlled firms, we find that the average board size for the descendant-controlled firms is significantly larger than that of the founder-controlled firms. In addition, the ratios of family-related supervisors and board members of the descendant-controlled firms are significantly higher than those of the matching founder-controlled firms. These findings are consistent with the conjecture by Morck, Shleifer, and Vishny that the descendants are too entrenched and, therefore, cannot to be removed by shareholders. Therefore, we conclude that family control has undermined the internal monitoring mechanisms of our sample of descendent-controlled firms.

The rest of the paper is organized as follows. The next section provides a review of related literature. Section three contains data description and univariate test results. Section four discusses the results from multivariate analysis. The final section concludes this study.

\section{Literature Review}

Since Berle and Means first established the agency theory of the modern corporations in 1932, the whole stream of agency theory literature focuses on the agency problems created by the separation of ownership and the control of resources acquired by ownership. Jensen and Meckling (1976) argue that when the owner-manager sells off a proportion of his ownership or borrows a lump-sum from the money market, there exists an incentive for him to favor his personal interest at the expenses of other stakeholders. Fama and Jensen (1983) analyze agency problems on the basis of residual claims. They propose that the owners of an organization are the ones bearing the 
residual risk - the risk of difference between the inflows of resources and outflows of promised payments. The organizational form that separates management from control leads to less restrictive residual-risk bearing, and thus a more diffused ownership structure. Demsetz (1983) examines agency problems based on potential on-the-jobconsumption by managers. He contends that there are two sources of on-the-job consumption: the known individual consumption that reflects the personal preference of the owner-manager, and the unknown individual consumption shirking, which reflects the monitoring costs borne by the company. The diffusion of ownership for a business organization involves trade-offs between on-the-job consumption by the managers and the monitoring costs borne by the company.

Jensen and Meckling (1976), Fama and Jensen (1983), and Demsetz (1983) suggest an intertwined relationship between corporate ownership and agency costs. Built on these fundamental blocks, most researchers have focused on U.S. firms in investigations of the relationship between managerial ownership and firm performance. Demsetz and Lehn (1985) first examine the determinants of corporate ownership concentration and the effects of ownership concentration on firm performance. However, they do not find a significant relationship between ownership concentration and the accounting performance of their sample of firms. Morck, Shleifer and Vishny (1988) provide evidence that contrasts to Demsetz and Lehn. With piece-wise regression, they find a nonlinear relationship between board ownership and Tobin's Q. Their results show that in the low range of board ownership, Tobin's Q increases when board ownership increases. After the board ownership reaches five percent of the total outstanding shares, Tobin's Q decreases as board ownership increases. McConnell and Servaes (1990) report a similar relationship between Tobin's Q and insider ownership -- shares owned by board members plus managers.

La Porta, Lopez-de-Silanes, and Shleifer (1998) provide the first broad investigation of the equity ownership across countries. The authors examine ownership structure of the publicly listed firms of 47 wealth countries and report that the majority of their sample firms are run and held by controlling families. They point out that family control of publicly traded firms is the norm in the non-U.S. world. However, the existing literature provides little evidence on the characteristic of the controlling families and how these controlling families affect firm performance. DeAngelo and DeAngelo (1985), Holderness and Sheehan (1988) and Denis and Denis (1994) are the few studies that examine family control of publicly listed U.S. firms. They do not find evidence of expropriation of minority shareholders' wealth by the controlling families. However, since their sample firms are all majority-owned by the controlling families, they cannot disentangle the family-control effects from the ownership effects.

Morck, Shleifer and Vishny (1988), McConaughy, Walker, Henderson and Mishra (1998) and McConaughy and Phillips (1999) are among a few studies that examine the relationship between founder control and firm characteristics of publicly listed U.S. firms. Morck, Shleifer and Vishny, examine the founder effect on firm performance. They report that the presence of the founding family as the two top officers -- the CEO and the president -- reduces firm value for firms incorporated before 1950, but increases firm value for those incorporated in 1950 or later. The authors conjecture that "in young firms founders play an important entrepreneurial role, whereas in older firms they or especially their descendants thwart value maximization and are too entrenched to be removed (page 311)." McConaughy, Walker, Henderson and Mishra investigate the efficiency of the U.S. founding family controlled firms (FFCFs), "firms whose CEO are either the founder or a descendant of the founder (page one)". Using three-year average data (1986-1988) of 73 pairs of FFCFs and non-FFCFs, they show that FFCFs are more efficient than the matching non-FFCFs. They also find that younger FFCFs are more efficient than older ones. McConaughy and Phillips compare the profitability and efficiency of 90 founder-controlled U.S. firms vis-à-vis 57 U.S. firms controlled by descendents or relatives of the founders, i.e., firms whose CEO are either a descendant or a relative of the founder. Their results show that founder-controlled firms grow faster and invest more heavily in research and development; however, descendant-controlled firms are more profitable.

La Porta, Lopez-de-Silanes, Shleifer, and Vishny (1998) investigate the influences of different legal systems on corporate governance structure. They contend that the legal and institutional framework has a direct influence on minority shareholder protections. According to the origin of a country's legal system, the authors categorize the 49 countries in their study into four groups: the English-origin, the French-origin, the German-origin, and the Scandinavian-origin. Their study shows that countries in the English common law system score the highest 
in minority shareholder protections, while countries in the French civil law system score the lowest. The Taiwanese system, which has its origin in German civil law, is categorized as relatively weaker in minority shareholder protections than the U.S. and the U.K. systems, both based on English common law. The authors argue that diffused equity ownership is less likely to arise in countries with weak legal protections for minority shareholders. They propose that in markets with relatively weaker legal protections, insider ownership substitutes for external monitoring. In light of the mixed results documented for the U.S. firms, this study provides new evidence on the characteristics of founder-controlled and descendant-controlled firms in a market dominated by family-controlled firms but with relatively weaker minority shareholder protections.

\section{Data Description and Univariate Analysis}

Our main data source is the data bank constructed by Taiwan Economic Journal Co., Ltd. (TEJ). Founded in 1990, TEJ is the largest commercial vender of capital-market data in Taiwan. It also contributes to many other databases, which include Datastream International, Ltd., Worldscope, QUICK, BARRA, and Capital Interactive Prospective. TEJ constructs its database based on the information published in (1) the Taiwan Securities and Exchange Commission Statistics Year Book, (2) the prospectus and quarterly, semi-annual, and annual reports filed with the TSEC by all listed companies, and (3) articles and announcements published in the local newspapers.

The study covers a period of eight years from 1990 through 1997. The Asian crisis started in August 1997, and eventually hit the Taiwanese market in early 1998. To avoid potential problems related to the crisis, we use data up to 1997. To ensure that we have at least four years of financial data for each firm, we require sample firms to be listed before the end of 1994. As in other newly developing markets, the Taiwanese firms are relatively young. The average listing age of the whole sample is 10.6 years; therefore, most of the listed firms are still under the control of the founders. Of the 299 firms listed by the end of 1994, only thirty-six firms are descendant-controlled. Following McConaughy and Phillips (1999), we identify the matching founder-controlled firms by screening firms in the same industry with average sales falling in the range of plus or minus $25 \%$. We find that most of the Taiwanese descendant-controlled firms are older and larger than their industry counterparts. We cannot identify a proper matching firm for six firms because they are among the largest in their industries. Our final sample includes 30 pairs of descendant-controlled firms and their matching counterparts. Table 1 provides the distribution of the sample firms in different industries and the number of firm-years of data included in our study.

\section{Fixed-effect Panel Analysis}

The evidence from our univariate analysis suggest that the sample descendant-controlled firms are statistically no different from the matching founder-controlled firms in size (measured by sales and total assets), growth potential (measured by R\&D expenditures per 1,000 dollars of assets) and financial leverage (measured by debt to total assets ratio). Prior studies indicate that these variables are major determinants of firm performance ${ }^{1}$. To assess the incremental effects of the descendant-controlled firms vis-à-vis the founder-controlled firms, it is crucial to include these variables in multivariate analysis. We run multivariate regressions using different performance measures as the dependent variable. The independent variables include a dummy variable, SND, which equals one if a firm is descendant-controlled and zero otherwise. In addition, we include the logarithm of total assets, the ratio of the R\&D expenditures to total assets, the ratio of total debt to total assets, and the number of years since the company was founded as control variables. By including these factors as independent variables we estimate the marginal explanatory power of the SND dummy variable on firm performance measures. Excluding these variables could bias the estimates for the SND dummy variable. In addition, we also investigate if industry effect was a critical factor in determining performance. To explore the industry effect, we estimate two sets of regressions, one using data adjusted for industry-level effects and the other with the raw data. To make the adjustment we subtract the industry-average of each variable from the data for each firm to obtain the industry-adjusted value of all the variables.

\section{Table 1}

\footnotetext{
${ }^{1}$ See Demsetz and Lehn (1985), Morck, Shleifer and Vishny (1988), and McConnell and Servaes (1990).
} 


\section{Distribution of sample firms and firm-year observations by industry}

This table reports our sample descendant-controlled firms, the matching founder-controlled firms and the firm-year observations in our study. Of the 299 publicly listed firms by the end of 1994, thirty-six are descendant-controlled. We identify the matching founder-controlled firms by screening firms in the same industry with average sales falling in the range of plus or minus $25 \%$. We exclude six of the descendant-controlled firms because they are among the largest in their industries, and we cannot find a matching counter part. Our final sample contains 60 firms and 434 firm-year observations across our study period, 1990-1997*.

\begin{tabular}{|c|c|c|c|}
\hline Industry & $\begin{array}{c}\text { Number of firms listed by } \\
\text { the end of } 1994\end{array}$ & $\begin{array}{c}\text { Number of descendent- } \\
\text { controlled firms in } \\
\text { our study } \\
\end{array}$ & $\begin{array}{c}\text { Number of firm-years } \\
\text { observation for both sample } \\
\text { and matching firms } \\
\end{array}$ \\
\hline Cement & 9 & 3 & 45 \\
\hline Food & 25 & 3 & 46 \\
\hline Plastic & 17 & 0 & 0 \\
\hline Textile & 45 & 4 & 64 \\
\hline Electric Machinery & 12 & 3 & 39 \\
\hline Electric Appliance \& Wire & 11 & 1 & 16 \\
\hline Chemical & 16 & 2 & 29 \\
\hline Glass \& Porcelain & 6 & 1 & 14 \\
\hline Paper \& Pulp & 7 & 0 & 0 \\
\hline Steel & 18 & 1 & 15 \\
\hline Rubber & 8 & 2 & 26 \\
\hline Auto & 4 & 0 & 0 \\
\hline Electronic & 32 & 3 & 37 \\
\hline Construction & 22 & 3 & 42 \\
\hline Transportation & 11 & 1 & 14 \\
\hline Tourist (Hotel) & 6 & 1 & 16 \\
\hline Banks \& Insurance Co. & 22 & 0 & 0 \\
\hline Department Stores & 7 & 1 & 16 \\
\hline Conglomerate Enterprise & 1 & 0 & 0 \\
\hline Others & 20 & 1 & 14 \\
\hline Total & 299 & $30 *$ & 434 \\
\hline
\end{tabular}

Table 2 reports the descriptive statistics and the univariate analysis of the sample and matching firms. The financial data in Panel A show that the Taiwanese descendant-controlled firms and founder-controlled firms are of similar size (measured both in average sales and average total assets.) Annual sales average NT $\$ 6,805$ million (US\$206 million) for descendant-controlled firms and NT\$6,440 million (US\$195 million) for the matching founder-controlled firms ${ }^{2}$. The mean total assets of our sample is NT $\$ 11,990$ million (US\$363 million) and NT $\$ 11,090$ million (US\$336 million) for the matching firms. Total debt to total assets ratio averages 0.38 for the sample firms and is similar to 0.37 for the matching firms. On average, the descendant-controlled firms spend US $\$ 7.2$ on R\&D for every US $\$ 1,000$ assets, while the matching founder-controlled firms spend US $\$ 7.0$ on R\&D for every US $\$ 1,000$ assets. Results of the univariate analysis suggest that the financial data of the matching foundercontrolled firms are not significantly different from that of our sample descendant-controlled firms.

Panel B reports the performance data. We employ seven different performance measures: market-to-book

\footnotetext{
2 The value of the New Taiwan dollar (NT\$) is determined under a managed float exchange rate regime. During the study period, the value of one U.S. dollar fluctuated in the range of NT $\$ 30$ to NT $\$ 35$. Because of the relatively narrow range, we felt comfortable in using the average exchange rate of NT\$33 per US\$, over the period, to convert the NT\$ amounts into US\$.
} 
ratio (Tobin's Q), net profit margin, operating profit margin, return on equity, return on assets, total assets turnover ratio, and operating income to total assets ratio. The univariate analysis shows that the descendant-controlled firms underperform their counterpart of founder-controlled firms in five performance measures. The two performance measures that are statistically indifferent between the two groups include: the mean net profit margin $(0.07$ for the descendant-controlled firm, and 0.08 for the founder-controlled firms), and the average total assets turnover ratio ( 0.64 for the sample descendant-controlled firms and 0.68 for the matching founder-controlled firms.)

Table 2

Comparative Statistics of Firm Characteristics and Performance Variables

Reported are the mean of the financial and performance data for the sample descendant-controlled firms and matching foundercontrolled firms. Panel A shows the average annual sales, book value of total assets, debt ratio and R\&D expenditures. Panel B reports the performance data. $\mathrm{N}$ is the number of firm-years of data for each group of firms. T-test statistics are in parentheses.

\begin{tabular}{|c|c|c|c|}
\hline Panel A. Financial Data & $\begin{array}{c}\text { Descendant- } \\
\text { controlled Firms }\end{array}$ & $\begin{array}{c}\text { Founder-controlled } \\
\text { Firms }\end{array}$ & Difference \\
\hline Number of firm-years of data & 215 & 219 & \\
\hline Sales (US\$ million) & 206 & 195 & $\begin{array}{c}9 \\
(0.69)\end{array}$ \\
\hline Book value of total assets (US\$ million) & 363 & 336 & $\begin{array}{c}27 \\
(1.08)\end{array}$ \\
\hline Debt ratio & 0.38 & 0.37 & $\begin{array}{c}0.01 \\
(0.22)\end{array}$ \\
\hline $\mathrm{R} \& \mathrm{D}$ expenditures per thousand dollar of assets & 7.2 & 7.0 & $\begin{array}{c}0.02 \\
(0.08)\end{array}$ \\
\hline \multicolumn{4}{|l|}{ Panel B. Performance Data } \\
\hline Market-to-book ratio (Tobin's Q) & 1.9 & 2.1 & $\begin{array}{l}-0.2 * * * \\
(-3.18)\end{array}$ \\
\hline Net profit margin & 0.07 & 0.08 & $\begin{array}{l}-0.01 \\
(-0.58)\end{array}$ \\
\hline Operating profit margin & 0.07 & 0.09 & $\begin{array}{c}-0.02 * * * \\
(-2.54)\end{array}$ \\
\hline Return on total assets & 0.04 & 0.05 & $\begin{array}{c}-0.01 * * * \\
(-2.55)\end{array}$ \\
\hline Return on equity & 0.06 & 0.08 & $\begin{array}{c}-0.02 * * * * \\
(-2.38)\end{array}$ \\
\hline Operating profit to total assets ratio & 0.04 & 0.05 & $\begin{array}{c}-0.01 * * * * \\
(-3.30)\end{array}$ \\
\hline Total assets turnover ratio & 0.64 & 0.68 & $\begin{array}{c}-0.04 \\
(-1.19)\end{array}$ \\
\hline
\end{tabular}

*** Significant at 0.01 level; ** significant at 0.05 level; * significant at 0.10 level.

Table 3 


\section{OLS Regressions and Industry-level Fixed-effect Analysis}

This table presents the results of Ordinary Least Squares (OLS) regressions and industry-level fixed effects analysis of performance measures: market-to-book ratio (Tobin's Q), net profit margin, operating profit margin, return on equity, return on total assets, total assets turnover ratio, and operating profit to total assets ratio on SND - dummy variable for descendantcontrolled firms and control variables. SND equals one if descendant-controlled, and zero if otherwise. Regression 1 uses the raw data, while Regression 2 uses data adjusted for industry-level effects. Industry-adjusted values are obtained by subtracting the industry average from the raw data for all variables. Both regressions are run on the pooled sample. $\mathrm{N}$ is the number of firmyear observations in the regressions. Previous studies indicate that the logarithm of total assets, the R\&D expenditures per 1,000 dollar of total assets, and the ratio of total debt to total assets are important determinants of firm performance. To assess the marginal contribution of SND in explaining firm performance, we also include those variables in the regressions. In addition, intercept terms and year dummies are included for all regressions, but not reported. T-statistics of the coefficients are in parentheses.

\begin{tabular}{|c|c|c|}
\hline $\begin{array}{l}\text { Dependent Variables: } \\
\text { Performance measures }\end{array}$ & $\begin{array}{l}\text { Regression } 1 \\
\mathrm{~N}=434\end{array}$ & $\begin{array}{l}\text { Regression } 2 \\
N=434\end{array}$ \\
\hline Market-to-book ratio (Tobin’s Q) & $\begin{array}{l}-0.15 * * * \\
(-2.81)\end{array}$ & $\begin{array}{l}-0.18 * * * \\
(-3.65)\end{array}$ \\
\hline Adj- $R^{2}$ & 0.30 & 0.26 \\
\hline Net profit margin & $\begin{array}{l}-.02 \\
(-1.14)\end{array}$ & $\begin{array}{l}-0.02 \\
(-1.50)\end{array}$ \\
\hline $\operatorname{Adj}-R^{2}$ & 0.10 & 0.08 \\
\hline Operating profit margin & $\begin{array}{l}-0.03 * * * \\
(-3.50)\end{array}$ & $\begin{array}{l}-0.03 * * * \\
(-4.60)\end{array}$ \\
\hline Adj- $R^{2}$ & 0.16 & 0.16 \\
\hline Return on equity & $\begin{array}{l}-0.03 * * * \\
(-3.40)\end{array}$ & $\begin{array}{l}-0.03 * * * \\
(-4.30)\end{array}$ \\
\hline $\operatorname{Adj}-R^{2}$ & 0.12 & 0.16 \\
\hline Return on total assets & $\begin{array}{l}-0.02 * * * \\
(-3.64)\end{array}$ & $\begin{array}{l}-0.02 * * * \\
(-4.53)\end{array}$ \\
\hline $\operatorname{Adj}-R^{2}$ & 0.21 & 0.24 \\
\hline Total assets turnover ratio & $\begin{array}{l}-0.03 \\
(-0.95)\end{array}$ & $\begin{array}{l}-0.02 \\
(-0.94)\end{array}$ \\
\hline $\operatorname{Adj}-R^{2}$ & 0.20 & 0.08 \\
\hline Operating profit to total assets ratio & $\begin{array}{l}-0.02 * * * \\
(-4.12)\end{array}$ & $\begin{array}{l}-0.02 * * * \\
(-5.14)\end{array}$ \\
\hline $\operatorname{Adj}-R^{2}$ & 0.17 & 0.21 \\
\hline
\end{tabular}

*** Significant at 0.01 level; ** significant at 0.05 level; * significant at 0.10 level.

Table 3 presents the results from the multivariate analysis. Regression 1 shows the results the raw data, while Regression 2 uses the data that is adjusted for industry-level effects. In the presence of size, growth potential and financial leverage variables, the coefficient estimate for the SND dummy variable is highly significant and negative for five of the firm performance measures. These results are consistent with those from the univariate 
analysis. The sign and the magnitude of the coefficients estimated from the raw data and the industry-adjusted values are quite similar. These results suggest that the Taiwanese descendant-controlled firms underperform their matching founder-controlled firms. Our findings are consistent with those reported by Morck, Shleifer, and Vishny (1988), who conjecture that while the founders of their sample of younger U.S. firms (incorporated in 1950 or later) contribute entrepreneurship, the founders' descendants are too entrenched to be removed. To determine the reason why Taiwanese descendant-controlled firms underperform their counterparts we investigate whether the descendants are entrenched.

To understand why the descendant-controlled firms under perform founder-controlled firms, we examine the corporate governance structure as well as other internal mechanisms. According to La Port, Lopez-de-Silanes, Shleifer and Vishny (1998), the Taiwanese corporate governance system has its origin in German-civil-law, which provides relatively weaker legal protections than the U.S. English-common-law system. They further argued that insider ownership substitutes for external monitoring in markets with relatively weaker minority shareholder protection. The question, therefore, arise as whether higher insider ownership enhance firm performance for the Taiwanese firms? Demsetz and Lehn (1985) document a negative relationship between ownership concentration and firm size. Given that the average size of our sample of descendant-controlled firms is not significantly different from the matching sample of founder-controlled firms, we should expect insider ownership to be similar for both groups. The mean insider ownership for the descendant-controlled firms is 28 percent and 30 percent for the matching founder-controlled firms; with a t-statistic is 1.24 , there is no difference in the level of insider ownership between the two groups of firms. Nevertheless, in light of the argument advanced by La Port, Lopez-de-Silanes, Shleifer and Vishny (1998), we re-estimate the relationship between the performance measures and SND, and include insider ownership in the regressions to ensure that the coefficient estimates of SND are not biased by any relationship between insider ownership and the SND variable. The results from these regressions are reported in Table 4. While the coefficient estimate for insider ownership stays significant and positive across all performance measures, the coefficient estimate for SND stays similar to those reported in Table 3. This finding suggests that insider ownership is not the reason why the descendant-controlled firms underperform the founder-controlled firms. Our focus now shifts to the board characteristics as potential monitoring mechanisms.

Table 4

Regression Analysis of Firm Performance with Equity Ownership Included in Models

This table presents regression results of the performance measures: market-to-book ratio (Tobin's Q), net profit margin, operating profit margin, return on equity, return on total assets, total assets turnover ratio, and operating profit to total assets ratio on SND dummy variable and insider ownership. SND equals one if descendant-controlled, and zero otherwise. Insider ownership is the equity ownership of directors, supervisors, and managers, including the holdings by their spouses and minor children. Previous studies indicate that the logarithm of total assets, the R\&D expenditures per 1,000 dollar of total assets, and the ratio of total debt to total assets are important determinants of firm performance. To assess the marginal contribution of SND in explaining firm performance, we also include these variables in the regressions. In addition, intercept terms and year dummies are included for all regressions, but the estimates are not reported. $\mathrm{N}$ is the number of firm-years of data used in the regressions. T-statistics of the coefficients are in parentheses.

\begin{tabular}{|c|c|c|c|c|c|c|c|}
\hline $\begin{array}{l}\text { Dependent Variables: } \\
\text { Industry-adjusted } \\
\text { Performance Measures }\end{array}$ & $\begin{array}{l}\text { Tobin's } Q \\
N=434\end{array}$ & $\begin{array}{l}\text { NPM } \\
N=434\end{array}$ & $\begin{array}{l}\text { OPM } \\
N=434\end{array}$ & $\begin{array}{l}\text { ROE } \\
N=434\end{array}$ & $\begin{array}{l}\text { ROA } \\
N=434\end{array}$ & $\begin{array}{l}\text { TAT } \\
\mathbf{N}=434\end{array}$ & $\begin{array}{l}\text { OPTA } \\
N=434\end{array}$ \\
\hline SND Dummy Variable & $\begin{array}{l}-0.17 * * * \\
(-3.24)\end{array}$ & $\begin{array}{l}-.02 \\
(-1.36)\end{array}$ & $\begin{array}{l}-0.03 * * * \\
(-4.46)\end{array}$ & $\begin{array}{l}-0.03 * * * \\
(-4.17)\end{array}$ & $\begin{array}{l}-0.02 * * * \\
(-4.41)\end{array}$ & $\begin{array}{l}-0.2 \\
(-0.98)\end{array}$ & $\begin{array}{l}-0.02 * * * \\
(-5.01)\end{array}$ \\
\hline Insider ownership & $\begin{array}{l}0.34 * \\
(1.92)\end{array}$ & $\begin{array}{l}0.11 * * \\
(2.33)\end{array}$ & $\begin{array}{l}0.09 * * * \\
(3.95)\end{array}$ & $\begin{array}{l}0.07 * * * \\
(2.68)\end{array}$ & $\begin{array}{l}0.04 * * * \\
(2.68)\end{array}$ & $\begin{array}{l}-0.05 \\
(-0.66)\end{array}$ & $\begin{array}{l}0.03 * * * \\
(2.68)\end{array}$ \\
\hline Adj- $R^{2}$ & 0.26 & 0.09 & 0.19 & 0.18 & 0.25 & 0.08 & 0.22 \\
\hline
\end{tabular}

Shleifer and Vishny (1986) advance the hypothesis that the dominant equity ownership of U.S. firms by 
institutional investors provides a strong incentive for the institutional shareholders to monitor the CEO. McConnell and Servaes (1990) report a positive relationship between firm performance and equity ownership of institutional investors for their sample of U.S. firms. In support of the role of institutional investors as active shareholders to enhance managerial accountability Cheffins (1999) cite U.K. corporate governance reform during the 1990s as reflected in the Combined Code of the U.K. We examine equity ownership of institutional shareholders for the two groups. The institutional equity holdings average around 0.06 percent for both groups and are statistically the same. Therefore, the absence of outside blockholders leaves the minority shareholders of our sample of Taiwanese firms dependent upon internal monitoring mechanisms to protect them from exploitation by the controlling families.

In their survey of the U.S. economic literature on the board of directors as a determinant of firm performance, Hermalin and Weisbach (2000) report that board size is negatively related to firm performance. In addition, their survey suggests that board composition and size are important factors in the board's decisions regarding CEO turnover, acquisitions, adoption of poison pills and CEO compensation. The Taiwanese board structure is a hybrid between the U.S. and the U.K. model of a unitary board and the German two-tier structure. The Taiwanese board of directors is the equivalent of the German managerial board and the Taiwanese supervisors are the designated monitors of the CEO and the board of directors. The role of the Taiwanese board of directors is similar to that ascribed to U.S. inside board members, while the role of the Taiwanese supervisors is similar to that associated with U.S. outside board members. If family control undermines the designated functions of the supervisors and/or the board of directors, firm performance should suffer. We test this hypothesis by screening the relationship between the board of directors and the CEO, and the relationship between the supervisors and the CEO. Members of the board of directors and supervisors are categorized as family-related if: (1) they have blood or marriage ties with the CEO, or (2) they are employed by other affiliated companies that are majority-owned by the CEO's family. We use the last names of directors and supervisors to identify blood and marriage ties to the CEO.

We also use the organizational charts and family trees in the Business Groups in Taiwan published by China Credit Information Service, Ltd., to confirm the relationship among corporate insiders. ${ }^{3}$

Table 5 provides comparisons of the board characteristics of our sample of Taiwanese firms. The size of the boards of descendant-controlled firms averages 12.7 directors, and is significantly larger than the average board size of 9.7 directors for the founder-controlled firms. On average, the descendant-controlled firms have 3 supervisors, which is significantly larger than the average of 2.4 supervisors for the founder-controlled firms. We also find that the descendant-controlled firms have significantly higher family representation on the board of directors and supervisors. Jensen (1993) contends that a large board size makes effective communication among board members more difficult, which in turn hinders firm performance. Yermack (1996) provides empirical evidence of an optimal board size of around nine directors for his sample of U.S. firms. The significantly larger board size combined with the stronger family domination of the board of directors and supervisors for the descendant-controlled firms suggest a potential power struggle between the controlling family and the non-family related board members and supervisors of the descendant-controlled firms.

Table 5

\footnotetext{
${ }^{3}$ The main contribution of this data source is that it provides detailed information on the management teams of all the affiliations controlled by the controlling family. According to TEJ, these managers constitute conveniently a pool of figureheads for members of the controlling family. This allows us to verify the true independence of the board of directors and supervisors who do not carry the same last names (surnames). Based on this additional information, we consider the board of directors and supervisors who do not have the same last names but are listed in the management teams as family-related.
} 


\section{Comparison of the Board Characteristics of Sample Firms}

We report the characteristics of the board of directors and supervisors for a sample of descendant-controlled firms and matching founder-controlled Taiwanese firms. The Taiwanese supervisors are the designated monitors of the CEO and the board of directors. The role of the Taiwanese board of directors is similar to that ascribed to U.S. inside board members, while the role of the Taiwanese supervisors is similar to that expected of U.S. outside board members. Members of the board of directors and supervisors are categorized as family-related if: (1) they have blood or marriage ties with the CEO, or (2) they are employed by other affiliated firms, which are majority-owned by the CEO's family.

\begin{tabular}{|c|c|c|c|}
\hline $\begin{array}{l}\text { Composition of the Board of Directors } \\
\text { and Supervisors }\end{array}$ & $\begin{array}{l}\text { Descendant- } \\
\text { controlled Firms }\end{array}$ & $\begin{array}{l}\text { Founder-controlled } \\
\text { Firms }\end{array}$ & Difference \\
\hline Number of firm-years of data & 215 & 219 & \\
\hline Board size & 12.7 & 9.7 & $\begin{array}{l}2.9 * * * \\
(5.02)\end{array}$ \\
\hline Average number of supervisors & 3.0 & 2.4 & $\begin{array}{l}0.6 * * * \\
(-3.84)\end{array}$ \\
\hline Family-related board of directors & 8.1 & 5.0 & $\begin{array}{l}3.1 * * * \\
(5.13)\end{array}$ \\
\hline The ratio of family-related board members to total & 0.70 & 0.56 & $\begin{array}{l}0.14 * * * \\
(5.98)\end{array}$ \\
\hline Family-related supervisors & 2.2 & 1.2 & $\begin{array}{l}1.0 * * * \\
(7.65)\end{array}$ \\
\hline The ratio of family-related supervisors to total & 0.72 & 0.57 & $\begin{array}{l}0.15 * * * \\
(4.39)\end{array}$ \\
\hline
\end{tabular}

*** Significant at 0.01 level; ** significant at 0.05 level; * significant at 0.10 level.

To assess the incremental explanatory power of SND after controlling for the effects of the characteristics of the board and supervisors, we include two additional variables to the multivariate analysis. The two variables are the ratio of family-related board of directors to total board members and the ratio of family-related supervisors to total supervisors. Again, we run multivariate regressions on both the industry-adjusted values and the raw data. Since the results for net profit margin and total assets turnover ratio are still insignificant we do not report those results. Also, the results for the industry-adjusted and the raw data are similar; thus we report only those obtained with industry-adjusted values in Table 6. Contrary to our expectation, the results in Table 6 show that the coefficient estimates for SND stay negative and highly significant, while the board and supervisor composition variables are insignificant across all performance measures. These results indicate that the board and supervisor composition variables do not have incremental explanatory power or in any way interfere with the influence of descendant control on firm performance. Together, our findings suggest that family domination of the board of directors and supervisors for Taiwanese descendant-controlled firms has undermined the designated functions of the internal monitoring mechanism and hindered firm performance. Johnson, Pa Porta, Lopez-de-Silanes, and Shleifer (2000) investigate the effects of tunneling on firm performance. They point out that tunneling can take place in many different forms. Their investigation focuses on the "legal" tunneling that happens in developed civil law countries. Our finding for the Taiwanese descendant-controlled firms provides empirical evidence of entrenchment. With a dominant number of family-related members serving as board members and supervisors, the CEO of the descendant-controlled firms can transfer wealth from the company to his or her own family. This transfer may include the assets or profits of firms, or it may be in the form of hiring unqualified family members.

Table 6 


\section{Regression Analysis of Firm Performance with Equity Ownership and Board Structure Variables Included in Models}

This table presents the results of industry-level fixed regressions of performance measures: market-to-book ratio (Tobin's Q), operating profit margin, return on equity, return on total assets, and operating profit to total assets ratio on SND dummy variable, insider ownership and board structure. SND equals one if descendant-controlled, and zero otherwise. Insider ownership is the equity ownership of directors, supervisors, and managers, including the holdings by their spouses and minor children. Previous studies indicate that the logarithm of total assets, the R\&D expenditures per 1,000 dollar of total assets, and the ratio of total debt to total assets are important determinants of firm performance. To assess the marginal contribution of SND in explaining firm performance, we also include these variables in the regressions. In addition, intercept terms and year dummies are included for all regressions, but the estimated coefficients not reported. $\mathrm{N}$ is the number of firm-years of data used in the regressions. Tstatistics for the corresponding coefficient estimates are in parentheses.

\begin{tabular}{|c|c|c|c|c|c|}
\hline $\begin{array}{l}\text { Dependent Variables: } \\
\text { Industry-adjusted Performance } \\
\text { Measures }\end{array}$ & $\begin{array}{l}\text { Tobin's Q } \\
\mathrm{N}=434\end{array}$ & $\begin{array}{l}\text { OPM } \\
\mathrm{N}=434\end{array}$ & $\begin{array}{l}\mathrm{ROE} \\
\mathrm{N}=434\end{array}$ & $\begin{array}{l}\text { ROA } \\
\mathrm{N}=434\end{array}$ & $\begin{array}{l}\text { OPTA } \\
\mathrm{N}=434\end{array}$ \\
\hline $\begin{array}{l}\text { Ratio of family-related board of } \\
\text { directors to all directors }\end{array}$ & $\begin{array}{l}0.05 \\
(0.32)\end{array}$ & $\begin{array}{l}0.02 \\
(0.99)\end{array}$ & $\begin{array}{l}0.03 \\
(1.41)\end{array}$ & $\begin{array}{l}0.02 \\
(1.45)\end{array}$ & $\begin{array}{l}0.01 \\
(0.98)\end{array}$ \\
\hline $\begin{array}{l}\text { Ratio of family-related supervisors } \\
\text { to all supervisors }\end{array}$ & $\begin{array}{l}-0.04 \\
(-0.43)\end{array}$ & $\begin{array}{l}0.02 \\
(1.49)\end{array}$ & $\begin{array}{l}-0.01 \\
(-0.70)\end{array}$ & $\begin{array}{l}-0.00 \\
(-0.63)\end{array}$ & $\begin{array}{l}-0.00 \\
(-0.31)\end{array}$ \\
\hline SND Dummy Variable & $\begin{array}{l}-0.17 * * * \\
(-3.24)\end{array}$ & $\begin{array}{l}-0.04 * * * \\
(-4.98)\end{array}$ & $\begin{array}{l}-0.03 * * * \\
(-4.22)\end{array}$ & $\begin{array}{l}-0.02 * * * \\
(-4.47)\end{array}$ & $\begin{array}{l}-0.02 * * * \\
(-4.91)\end{array}$ \\
\hline Insider ownership & $\begin{array}{l}0.35^{* *} \\
(1.97)\end{array}$ & $\begin{array}{l}0.08 * * * \\
(3.39)\end{array}$ & $\begin{array}{l}0.06 * * \\
(2.28)\end{array}$ & $\begin{array}{l}0.03 * * \\
(2.29)\end{array}$ & $\begin{array}{l}0.03 * * \\
(2.27)\end{array}$ \\
\hline Adj- $R^{2}$ & 0.26 & 0.19 & 0.18 & 0.25 & 0.22 \\
\hline
\end{tabular}

*** Significant at 0.01 level; ** significant at 0.05 level; $*$ significant at 0.10 level.

\section{Conclusion}

This study investigates the performance difference between Taiwanese descendant-controlled firms and founder-controlled firms and expands to the existing literature by providing new evidence that enhances our understanding of how family control affects the performance of publicly traded firms. After adjusting for size, age, growth potential, financial leverage, and industry effects, we find that Taiwanese descendant-controlled firms underperform a matching sample of founder-controlled firms. Morck, Shleifer, and Vishny (1988), report similar results for their sample of U.S. firms, and conjecture that the descendants are entrenched and therefore cannot be removed. Our investigation of entrenchment hypothesis reveals that the average board size for the descendantcontrolled firms is significantly larger than that of the founder-controlled firms. In addition, the ratios of familyrelated supervisors and board members of the descendant-controlled firms are significantly higher than that of the matching founder-controlled firms. While the significantly larger board size suggests a potential power struggle between the controlling family and the non-family related board members, the stronger family domination on the board of directors and supervisors for the descendant-controlled firms provides room for entrenchment. In light of the absence of large outside blockholders and relatively weaker legal protections, the minority shareholders in the Taiwan market are dependent on internal monitoring mechanisms to protect them from the exploitation by the controlling families. However, our results indicate that family control has undermined the internal monitoring mechanism of the Taiwanese descendant-controlled firms.

\section{References}


1. Berle, Jr., A. and G. Means, 1932, The modern corporation and private property, MacMillan Company, New York.

2. Cheffins, B., 1999, Current trends in corporate governance: going from London to Milan via Toronto Duke, Journal of Comparative \& International Law 10:5, 5-42.

3. DeAngelo, H., and L. DeAngelo, 1985, Managerial ownership of voting rights, Journal of Financial Economics 14, 33-69.

4. Demsetz, H., 1983, The structure of ownership and the theory of the firm, Journal of Law and Economics 26, 375-393.

5. Demsetz, H., and K. Lehn, 1985, The structure of corporate ownership: causes and consequences, Journal of Political Economy 93, 1155-1177.

6. Denis, D. and D. Denis, 1994, Majority owner-managers and organizational efficiency, Journal of Corporate Finance 1, 91-118.

7. Fama, E. and M. Jensen, 1983, Agency problems and residual claims, Journal of Law and Economics 26, 327-349.

8. Hermalin, B. and M. Weisbach, 2000, Boards of directors as an endogenously determined institution: a survey of the economic literature, Economic Policy Review, forthcoming.

9. Holderness, C. G. and D. Sheehan, 1988, The role of majority shareholders in publicly held corporations -an exploratory analysis, Journal of Financial Economics 20, 317-346.

10. Jensen, M., 1993, The modern industrial revolution, exit and the failure of internal control systems, Journal of Finance 48, 831-880.

11. Jensen, M. and W. Meckling, 1976, Theory of the firm: managerial behavior, agency costs, and ownership structure, Journal of Financial Economics 3, 305-360.

12. Johnson, S., R. La Porta, F. Lopez-de-Silanes, and A. Shleifer, 2000, Tunneling. Working Paper.

13. La Porta, R., F. Lopez-de-Silanes, A. Shleifer, and R. Vishny, 1998, Law and Finance, Journal of Political Economy 106, 1115-1155.

14. La Porta, R., F. Lopez-de-Silanes, and A. Shleifer, 1998, Corporate ownership around the world, Journal of Finance 54, 471-517.

15. McConaughy, D., M. Walker, G. Henderson, and C. Mishra, 1998, Founding family controlled firms: efficiency and value, Review of Financial Economics 7, 1-19.

16. McConaughy, D., and G. Phillips, 1999, Founders versus descendants: the profitability, efficiency, growth characteristics and financing in large public founding-family-controlled firms, Family Business Review 12(2), 123-131.

17. McConnell, J., and H. Servaes, 1990, Additional evidence on equity ownership and corporate value, Journal of Financial Economics 27, 595-612.

18. Morck, R., A. Shleifer, and R. Vishny, 1988, Management ownership and market valuation: an empirical analysis, Journal of Financial Economics 20, 293-315.

19. Shleifer, A., and R. Vishny, 1997, A survey of corporate governance, Journal of Finance 52, 737-783.

20. Yermack, D., 1996, Higher valuation of companies with a small board of directors, Journal of Financial Economics 40, 185-212. 